\title{
A NEW GENUS AND SPECIES OF FLOUNDER ( $F$. PLEURONECTIDAE) WITH NOTES ON OTHER TASHANIAN SPECIES
}

\author{
by P.R. Last \\ Tasmanian Fisheries Development Authority, Research \& \\ Resources Section; Taroona, Tasmania
}

(with two tables and one plate)

\section{ABSTRACT}

Six species of pleuronectids, Ammotretis iiturata (Richardson), A. macrolepis McCulloch, A. rostratus Günther, Azygopus pinnifasciatus Norman, Rinombosolea tapirina Günther and Taratretis derwentensis gen. et. sp. nov., are found in Tasmanian waters and a key for their identification is given. The new genus is defined and the species described. In addition, Ammotretis tudori McCulloch is placed in synonymy with $A$. liturata and notes on $R$. tapirina are provided. A second known specimen of $A$. macrolepis is described and the features which distinguish it from $A$. Ziturata are noted.

\section{INTRODUCTION}

The family Pleuronectidae is represented in Australia by two subfamilies. One of these, the Samarinae, is represented by a single species recorded only from Queensland. The second subfamily, the Rhombosoleinae, is exclusively a Southern Ocean group with six of the eight known genera recorded from Australia and New Zeal and (Norman 1934).

Johnston (1883, 1891) listed four species of pleuronectids from Tasmania, Ammotretis rostratus Günther, Rhombosolea monopus Günther, Rhombosolea topirina Ginther, and Solea liturata Richardson. McCulloch (1914) added Ammotretis macrolepis McCul1och and A. tudori McCulloch to this list. Lord and Scott (1924) add Rhombosolea flesoides Günther but omit $R$. monopus and $S$. Ziturata.

In his revision of the subfamily Rhombosoleinae, Norman (1926) recognized five species; all three Ammotretis species, $R$. topirina and a new species, Azygopus pinnifasciatus Norman. $R$. flesoides and $R$. monopus were male junior synonyms of $R$. tapirina and a New Zealand species, $R$. plebia Richardson, respectively. However he doubted the validity of Australian records of $R$. plebia and suggested that they were misidentifications of $R$. tapirina. Uncertain of the true position of $S$. Ziturata, Norman tentatively placed the species in synonymy with $A$. tudori.

These species are accepted by subsequent authors (Munro 1957, Scott 1962). However, McCulloch (1929) retained $S$. Ziturata as an Ammotretis species, distinct from $A$. tudori. The validity of $A$. macrolepis and its consequent exclusion from $A$. tudori has been questioned (Norman 1934), but the species which was described from a single specimen was retained.

In the following paper a new rhombosolein fish is added to the Tasmanian records. The validity of $A$. macrolepis and $A$. Liturata are also discussed.

\section{METHOD}

A total of 26 measurements (table 1) was recorded from specimens of Amotretis macrolepis, A. Iiturata and the new species. Most of these are standard measurements used by Lagler, Bardach and Miller (1962) but some require clarification. 


\section{A new genus and species of flounder}

The upper and lower snout measurements refer to the direct lengths from the tip of the snout to the anterior margins of the upper and lower eyes respectively; the eye length being the longitudinal diameter of the upper eye. Apart from fin ray heights, a11 measurements were direct; the maximum length of the longest ray of the appropriate fin was used for each fin ray measurement.

Measurements presented in tables $1 \& 2$ are expressed as thousands of standard length (S.L.); the standard lengths being given in millimetres.

The transverse scale count ( $\mathrm{Tr}$ ) was taken from the dorsal border above the pectoral fin origin, transversely to the anal fin.

Means and modal values for measurements and fin counts, respective1y, are bracketed in the species description.

The range ( $R$ ) of a ratio of the number of rays in the right and left pelvic rins, $\mathrm{Pr}$ and $\mathrm{P} 1$ respectively, was used as a key character. This pelvic ratio (P.R.) was designated by:

$$
\begin{aligned}
& P . R .=\frac{P r}{P 1} \text { and } R=P \cdot R \cdot \operatorname{minimum}-P \cdot R \cdot \operatorname{maximum} \text { where } \\
& \text { P.R.minimum }=\frac{\mathrm{Pr}_{\text {minimum }}}{\mathrm{P} 1_{\text {maximum }}} \text { and } \mathrm{P} \cdot \mathrm{R} ._{\text {maximum }}=\frac{\mathrm{Pr}_{\text {maximum }}}{\mathrm{P} 1_{\text {minimum }}}
\end{aligned}
$$

\section{RESULTS AND DISCUSSION}

Six species of pleuronectids are hereby recognized as occurring in Tasmania and a key for their identification is given below. KEY TO THE TASMANIAN PLEURONECTIDAE

1. One pelvic fin.............................mbosolea tapimina Gunther

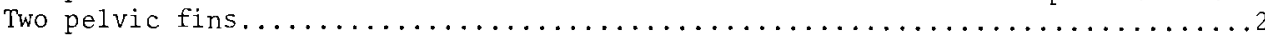

2. Right pelvic free from anal $(R=1.67-2.20) \ldots .$. Azygopus pinnifasciatus Norman

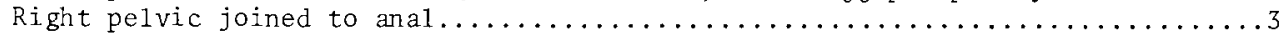

3. Sum of ray elements of both pelvics less than $13(10-12) \ldots \ldots \ldots \ldots \ldots \ldots \ldots$ Sum of ray elements of both pelvics greater than $13(15-17) \ldots \ldots \ldots \ldots \ldots \ldots \ldots$

4. Pelvic Ratio less than $1.50(1.00-1.20)$. Dorsal and anal fins naked. Snout not produced into fleshy hook. Anterior dorsal and right pelvic rays bifurcated, without blunt serrations.............Taratretis derwentensis gen. et. sp. nov. Pelvic Ratio greater than $1.50(1.75-2.33)$. Dorsal and anal fins scaled on ocular side. Snout produced into long fleshy hook. Anterior dorsal and right pelvic rays simple, serrated.......................motretis rostratus Günther

5. Pelvic Ratio less than $2.00(1.50-1.67)$. Left pectoral with fleshy tubercle; less than 0.65 length of right................. Ammotretis liturata (Richardson) Pelvic Ratio greater than $2.00(2.4)$. Left pectoral without tubercle; greater than 0.65 length of right................... Ammotretis macrolepis McCulloch

\section{Sub-family RHOMBOSOLEINAE}

Genus TARATRETIS gen. nov.

Genotype: Taratretis derwentensis sp. nov.

Diagnosis.

Body ovate, compressed. Eyes on right side; eyeballs not scaled. Interorbital space scaled. Jaws almost symmetrical. Snout not produced into a fleshy hook. Nasal organ of blind side nearly opposite to that of ocular side; olfactory laminae few, parallel to one another and to axis of the body, without central rachis. Dorsal fin commencing some distance from extremity of snout; anterior rays branched, not free and without distal serrations. Dorsal and anal fins scaleless, no basal sheath. Ventral rays branched. 
Affinities .

The position and structure of the nasal organ is important in the classification of the Heterosomata (Norman 1926, 1934). The median rachis of the nasal organ has been lost in the following four genera of Rhombosoleinae: Rhombosolea, Taratretis and the sole-like genera, Ammotretis and Peltoramohus.

Taratretis resembles Rhombosolea and differs from the sole-like genera in the anterior vertical fin ray structure and in the absence of a rostral hook. However the genus parallels Ammotretis and Peltoramphus in the other sole-like features outlined by Norman (1926). Most of these characters plus the presence of a left pelvic fin, are markedly different from those in Rhombosolea. Thus, in form, Taratretis would appear to be intermediate between Rhombosolea and the sole-like genera but possibly with an independent phylogeny.

Taratretis derwentensis sp. nov. P1ate 1

Material.

Holotype: $61.0 \mathrm{~mm} \mathrm{S.L.,} \mathrm{female,} \mathrm{collected} \mathrm{by} \mathrm{author} \mathrm{in} \mathrm{Derwent} \mathrm{Estuary} \mathrm{off}$ Nutgrove Beach $\left(147^{\circ} 21^{\prime} \mathrm{E}, 42^{\circ} 55^{\prime} \mathrm{S}\right)$, seined in 3 metres, 30.3.77. Tasmanian Mus eum Reg. No. D1305.

Paratypes: 18 specimens, all collected by author from Derwent Estuary: 2

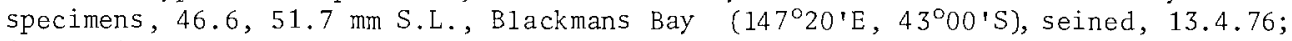
16 specimens, 27.0-62.6 mm S.L., Nutgrove Beach, seined, $16.1-14.2-28.2-30.3-$ 15.4 - 27.4.77 (Specimens to be distributed between the Australian Museum, Queen Victoria Museum and the Tasmanian Museum).

Other material: 2 specimens, $48.6,62.1 \mathrm{~mm}$ S.L., West Beach, Stanley $\left(145^{\circ} 15^{\prime} \mathrm{E}\right.$, $\left.40^{\circ} 45^{\prime} \mathrm{S}\right)$, seined by author $16.2 .78 ; 1$ specimen, 66.9 inm S.L., Hawley Beach, Port Sorell $\left(146^{\circ} 32^{\prime} \mathrm{E}, 41^{\circ} 09^{\prime} \mathrm{S}\right)$, seined by author, $18.2 .78 ; 1$ specimen, $86.2 \mathrm{~mm} \mathrm{~S} . \mathrm{L}$., Tinderbox Bay $\left(147^{\circ} 20^{\prime} \mathrm{E}, 43^{\circ} 04^{\prime} \mathrm{S}\right)$, dredged by Mr. M. Jacobson, 21.3.78.

\section{Description.}

Depth of body $2.02-2.34$ (2.22) in the length, head length $3.64-4.07$ (3.87) Snout short, not produced to form a hook, extending to level of middle lower eye. Lower eye slightly in advance of upper eye, each almost equidistant to ventral and dorsal profiles respectively. Longitudinal diameter of upper eye $3.0-4.2(3.6)$ head length; approximately equal to upper snout length; greater than eight times interorbital width. Mouth small, almost symmetrical, jaws equally curved on each side; lower lip on ocular side fringed. Teeth small, acutely pointed; in bands on $j$ aws of blind side and anterior part of mandible on ocular side. Maxillary extension variable, usually reaching to below anterior margin of lower eye. Nasal organs symmetrical, with pair of small pores on each side; anterior pores with simple tentacles on their posterior borders; 4 - 5 olfactory 1 aminae parallel to each other and to main axis of body; no central rachis. Upper angle of gill opening just above base of pectoral fins, gill rakers short, tubercular, $9-13$ (12) on lower part of anterior arch. Scales sma11, ctenoid, more denticulate on ocular side; entire over head and body; imbricated in distinct longitudina1 rows; $75-83$ (79) in lateral 1ine; Tr 48 - 56 (51); eyeballs, dorsal and anal fins naked. Lateral line with a low curve above pectoral fin; a short supratemporal branch not reaching dorsal fin. Dorsal fin commencing away from snout apex, directly anterior to nasal organs; no basal sheath; rays bifid, not free or serrated, $70-80$ (75); membraneous folds on blind side well developed. Anal similar to dorsal, 51 - 59 (53) rays. Right pelvic originating over or behind mid-orbital level of lower eye; rays bifid, last two longest. Left pelvic shorter than right; 5 - 6 (6) rays, first opposite the fifth on ocular side. Right pectoral 8 - 11 (10) rays. Left pectoral $1.1-1.5(1.26)$ in right; $7-9$ (7) rays. Caudal rounded, all 


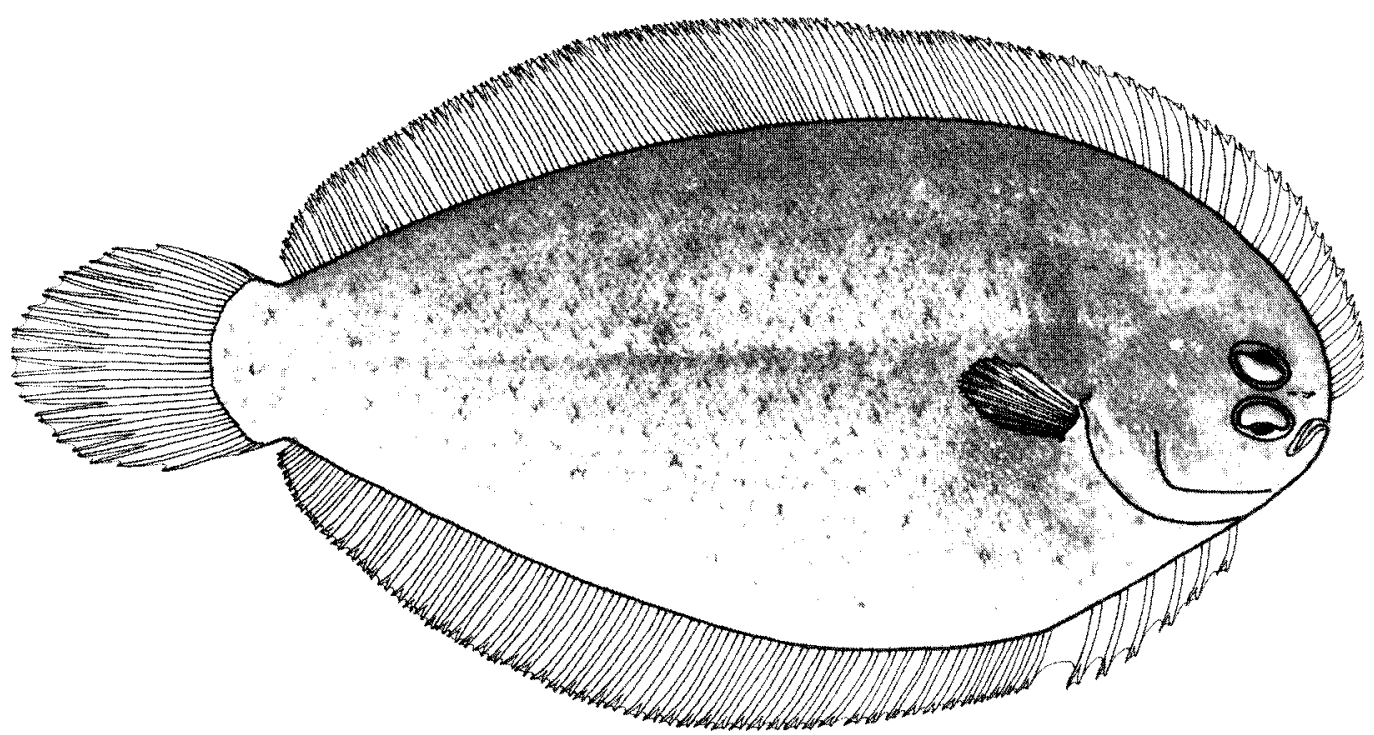

PLATE 1.- Taratretis derwentensis gen. et sp. nov.; holotype; $61.0 \mathrm{~mm}$ S.L.; seined in $3 \mathrm{~m}$ at Nutgrove Beach in the Derwent Estuary; 30.3.77. Tasmanian Museum Reg. No. D1305.

rays scaled on both sides to approximately half length of median rays; rays 18 , middle branched $10-13$ (12), outer sinple $4-8$ (6). Caudal peduncle short. Intestine elongate, about 3 times length of head ( 0.78 of S.L.).

Dimensions.

As given in table 1.

Coloration.

Natural - Ocular side sandy with numerous scattered light and dark areas each covering about 2 - 6 scales. Scale edges darker. Fin rays lighter interdispersed with orange and black markings; membranes transparent with irregular white areas over quarter of total area. Blind surface white. Formalin - Preserved specimens lighter, with pattem as above. Fins uniform light grey.

Size.

Largest specimen collected 102.4 min total length.

Distribution.

Evidence from initial sampling indicated that the species may be endemic to beaches in the vicinity of the Derwent Estuary, however specimens recently produced from two Bass Strait localities indicate a wider distribution pattern than first expected. 


\section{P.R. Last}

\section{TABLE 1}

TARATRETIS DERWENTENSIS GEN. ET SP. NOV.

Dimensions of Holotype and 18 Paratypes from the Derwent Estuary, southern Tasmania. First Line: standard length, absolute dimensions, mm; other lines: relative dimensions, thousandths of standard length.

\begin{tabular}{|c|c|c|c|c|c|}
\hline & Holoty & & & aratypes & \\
\hline & $x$ & Ran & & $\bar{x}$ & S.D. \\
\hline Standard length & 61.0 & 27.0 & -62.6 & 39.07 & - \\
\hline Total length & 1256 & 1215 & -1255 & 1236.0 & 2.99 \\
\hline Head & 246 & 248 & $-\quad 275$ & 258.3 & 1.73 \\
\hline Snout, upper & 64 & 60 & 78 & 70.3 & 1.00 \\
\hline Snout, lower & 56 & 41 & 66 & 49.5 & 1.21 \\
\hline Eye & 64 & 60 & 85 & 71.3 & 1.61 \\
\hline Interorbital & 5 & 3 & 7 & 5.2 & 0.28 \\
\hline Length base left pectoral fin & 26 & 19 & 27 & 23.6 & 0.57 \\
\hline Length left pectora 1 fin & 89 & 72 & 103 & 89.0 & 1.57 \\
\hline Length base right pectoral fin & 28 & 25 & 32 & 28.2 & 0.46 \\
\hline Length right pectoral fin & 118 & 101 & 118 & 112.0 & 1.14 \\
\hline Length base $1 \mathrm{eft}$ pelvic fin & 30 & 27 & 44 & 33.4 & 0.94 \\
\hline Height left pelvic fin & 62 & 58 & 89 & 74.4 & 1.55 \\
\hline Length base right pelvic fin & 153 & 137 & 182 & 156.1 & 2.75 \\
\hline Height right pelvic fin & 85 & 84 & 104 & 93.0 & 1.21 \\
\hline Length base dorsal fin & 982 & 943 & 986 & 966.8 & 2.59 \\
\hline Height dorsal fin & 118 & 106 & 145 & 123.4 & 1.89 \\
\hline Length base anal fin & 749 & 693 & 805 & 752.0 & 6.73 \\
\hline Height anal fin & 116 & 107 & 141 & 123.0 & 1.61 \\
\hline Length unbranched cauda 1 rays & 157 & 146 & 176 & 158.8 & 1.93 \\
\hline Length branched caudal rays & 241 & 213 & 267 & 235.2 & 3.19 \\
\hline Depth vent & 410 & 354 & 417 & 378.0 & 3.57 \\
\hline Depth maximum & 494 & 425 & 489 & 449.5 & 4.95 \\
\hline Depth caudal peduncle & 138 & 125 & 137 & 131.7 & 0.86 \\
\hline Length maxillary & 59 & 54 & 70 & 61.9 & 0.84 \\
\hline Length snout to vent & 257 & 253 & 319 & 285.1 & 4.42 \\
\hline
\end{tabular}

Genus AMMOTRETIS Günther, 1862

Ammotretis Ziturata (Richardson, 1843)

Synonym: Ammotretis tudori McCulloch, 1914

Material.

Seventeen specimens all collected by author and held in personal collection : 2 specimens, $156.0,241.4 \mathrm{~mm}$ S.L., St. Helens Point $\left(148^{\circ} 22^{\prime} \mathrm{E}, 41^{\circ} 16^{\prime} \mathrm{S}\right)$, speared, 5.12 .76 ; 6 specimens, $54.2-114.1 \mathrm{~mm}$ S.L., Nine Mile Beach, Swansea $\left(148^{\circ} 08^{\prime} \mathrm{E}\right.$, $42^{\circ} 06^{\prime}$ 'S), seined, 8.3.77; 1 specimen, $70.3 \mathrm{~mm} \mathrm{S.L.,} \mathrm{Kingston} \mathrm{Beach}\left(147^{\circ} 20^{\prime} \mathrm{E}, 42^{\circ} 58^{\prime} \mathrm{S}\right)$,

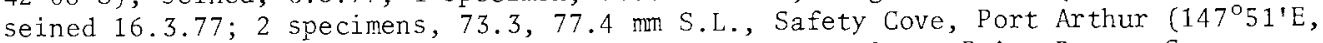
$\left.43^{\circ} 10^{\prime} S\right)$, seined, $30.3 .77 ; 5$ specimens, $54.9-62.5 \mathrm{~mm} \mathrm{S.L.,} \mathrm{Point} \mathrm{Bagot,} \mathrm{Swansea}$ $\left(148^{\circ} 14^{\prime} \mathrm{E}, 42^{\circ} 06^{\prime} \mathrm{S}\right)$, seined, $8.6 .77 ; 1$ specimen $265.3 \mathrm{~mm} \mathrm{S.L.,} \mathrm{Point} \mathrm{Bagot,} \mathrm{Swansea}$ $\left(148^{\circ} 14^{\prime} \mathrm{E}, 42^{\circ} 06^{\prime} \mathrm{S}\right)$, seined, 17.1 .78 .

Comments.

McCulloch (1914) described Ammotretis tudoni from Bass Strait and provided a key to the known members of the genus, which however did not include $A$. liturata 
(Richardson). Norman (1926) was first to recognize Richardson's species as an Ammotretis and considered it as possibly conspecific with $A$. tudori but failed to give reasons. Specimens collected from several localities around Tasmania, including Port Arthur the assumed type locality of A. Ziturata, fit the description of that species and are also conspecific with the holotype of $A$. tudori. These findings support Norman's sentiments, hence the two species are treated here as synonymous, with the older name $A$. Liturata taking precedence.

The question of synonymy would have been more reliably elucidated had the holotype of Richardson's species been examined. However a detailed literature search, followed by an investigation of the holdings of the Tasmanian, Queen Victoria and Australian Museums failed to locate the type and have raised doubts about its current existence.

Ammotretis macrolepis McCulloch, 1914

Material.

One specimen $55.1 \mathrm{~mm}$ S.L., off Flinders Island, Bass Strait, J. Grant, dredged from Tasmanian Sea Fisheries vessel 'Challenger', May 1977. Tasmanian Museum Reg. No. D1306.

\section{Comments.}

A comparison of Mr. Grant's specimen with the holotype indicates their similarity except that McCulloch's specimen exhibits a greater number of vertical fin rays; 90 dorsal and 59 anal rays compared with 80 and 52 rays respectively. Although the variation is considerable, it is not atypical for this group of fish. In comparison two less intraspecifically variable characters, namely the pelvic fin ray counts, are both identical for both specimens and unique to the genus.

Colour on the ocular side is light grey and white with faint evidence of darker ocelli. The blind side is white.

This species is most similar to $A$. Ziturata and its distinctness from that species has been questioned by Norman $(1926,1934)$. A. macrolepis differs primarily by the absence of blunt serrations on the edges of the anterior dorsal and right ventral rays, the absence of a fleshy tubercle on the right pelvic fin and the unique pelvic ratio.

A comparison of a number of different proportions (Table 2) made on similar sized specimens of the two species is of limited use because of small sample sizes, however some trends are evident. The relative eye diameters, the lengths of the longest unbranched caudal rays and the length and base lengths of the right pectoral fins show differences. The relative lengths of the bases of the anal and left pectorals are significantly different at the 0.01 level. The ratios of the pectoral lengths are very different for the two species ( $P$ less than 0.005 ). The left pectoral of $A$. macrolepis is slightly shorter than the right, however for $A$. Liturata a reduction in the left pectoral length has been accompanied by a comparative elongation of the right.

Genus RHOMBOSOLEA Günther, 1862

Rhombosolea topimina Günther, 1862

Those specimens previously identified as Rhombosolea sp. (Scott 1976), R. monopus (Johnston 1883, 1891) and $R$. flesoides (Lord and Scott 1924), appear to be misidentifications of the very variable species $R$. tapimina. Some specimens have assumed a very rhomboidal shape similar to $R$. plebia, whereas other adult characters including the form of the snout, are typical of $R$. tapirina. To complicate the issue the fleshy snout is usually reduced in juveniles. Clearly, if a second species does exist, it must be very similar externa1ly to $R$. topirina. 


\title{
P.R. Last
}

\section{TABLE 2}

COMPARATIVE MORPHOMETRY OF SMALL SAMPLES OF AMMOTRETIS LITURATA (RICHARDSON) AND A. MACROLEPIS MCCULLOCH

First line: standard length, absolute dimensions, m; other lines relative dinensions, thousand ths of standard length.

\author{
Standard length \\ Total length \\ Head \\ Snout, upper \\ Snout, lower \\ Eye \\ Interorbital \\ Length base left pectoral fin \\ Length left pectoral fin \\ Length base right pectoral fin \\ Length right pectoral fin \\ Length base left pelvic fin \\ Height left pelvic fin \\ Length base right pelvic fin \\ Height right pelvic fin \\ Length base dorsal fin \\ Height dorsal fin \\ Length base anal fin \\ Height anal fin \\ Length unbranched caudal rays \\ Length branched caudal rays \\ Depth vent \\ Depth maximum \\ Depth caudal peduncle \\ Length maxillary \\ Length snout to vent \\ Right pelvic ray count \\ Left pelvic ray count
}

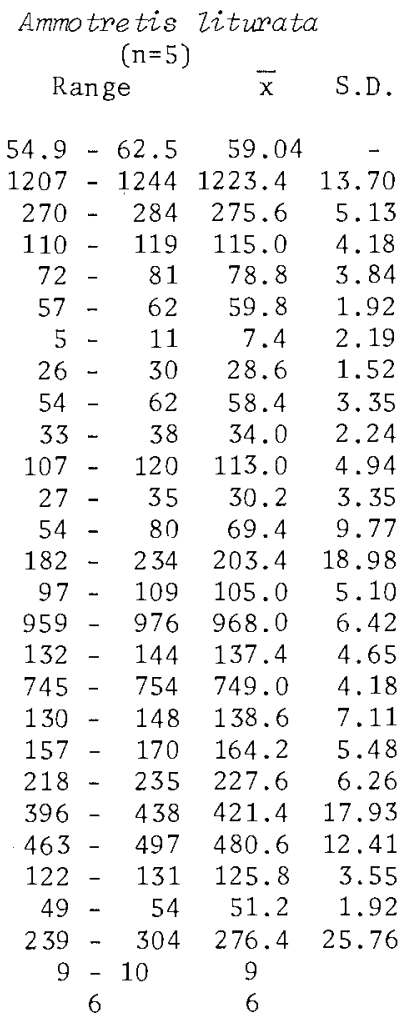

Ammotretis macrolepis

$x \quad t_{4}^{(n=1)}$ Signif.

$\begin{array}{rcc}55.1 & - & - \\ 1193 & 1.996 & - \\ 267 & 1.531 & - \\ 111 & 0.873 & - \\ 73 & 1.381 & - \\ 69 & 4.366 & * \\ 4 & 1.417 & - \\ 17 & 6.982 & \text { ** } \\ 68 & 2.607 & - \\ 26 & 3.266 & * \\ 95 & 3.320 & * \\ 40 & 2.673 & - \\ 57 & 1.157 & - \\ 189 & 0.692 & - \\ 120 & 2.685 & - \\ 951 & 2.469 & - \\ 129 & 1.642 & - \\ 715 & 7.641 & * * \\ 131 & 0.973 & - \\ 191 & 4.452 & * \\ 236 & 1.223 & - \\ 409 & 0.631 & - \\ 461 & 1.440 & - \\ 115 & 2.767 & - \\ 51 & 0.095 & - \\ 249 & 0.971 & - \\ 12 & & \\ 5 & & \end{array}$

A detailed study of the anatomy and morphometrics of Australian collections is necessary before this problem can be elucidated.

\section{ACKNOWLEDGEMENTS}

I wish to thank Messrs. S. Be11, P. Cramp, G. Edgar, P. Jarvis, V. Moss and D. Patten for their assistance in the collection of type material. I am also grateful to Mr. J. Grant of the Tasmanian Sea Fisheries for providing material from Bass Strait. Finaliy, I would like to thank Doctors R. Gaymer, E.R. Guiler and J.L. Hickman for critically reviewing the manuscript. 
REFERENCES

Johnston, R.M., 1883: General and critical observations on the fishes of Tasmania with a classified catalogue of all known species. Pap. Proc. R. Soc. Tasm., (1882), 58-144.

, 1891: Further observations on the fishes and fishing industries of Tasmania, together with a revised 1 ist of indigenous species. Pap. Froc. $R$. Soc. Tasm., (1890), 22-46.

Lagler, K.F., Bardach, J.E. and Miller, R.R., 1962: ICHTHYOLOGY. J. Wiley \& Sons, Inc. New York.

Lord, C.E. and Scott, H.H., 1924: A SYNOPSIS OF THE VERTEBRATE ANIMALS OF TASMANIA. oldham, Beddome and Meredith, Hobart.

McCulloch, A.R., 1914: Report on the fishes obtained by the F.I.S. 'Endeavour' on the coasts of Queensland, New South Wales, Victoria, South Australia and Tasmania, Part 2. Zool. Res. Endeavour, 2(3), 77-165, pls XIII-XXXIV, 15 figs.

, 1929: A check-1ist of the fishes recorded from Australia. Aust. Mus. Mem, 5(1-4) (part 4, Index, 1930) i - x, 1-534.

Munro, I.S.R., 1957: Handbook of Australian Fishes 16, 17, 65-72. Fisheries Newsletter (now Aust. Fisher.) $16(10,11)$.

Norman, J.R., 1926: A report on the flatfishes (Heterosomata) collected by the F.I.S. 'Endeavour', with a synopsis of the f1atfishes of Australia and a revision of the sub-family Rhombosolinae. Bio. Res. Endeavour, 5(5), 219-308, figs 1-15. , 1934: A SYSTEMATIC MONOGRAPH OF THE FLATFISHES (HETEROSOMATA): VOL 1. , PSETTODIDAE, BOTHIDAE, PLEURONECTIDAE. London, British Museum.

Scott, E.O.G., 1976: Observations on some Tasmanian Fishes: Part XXII. Pap. Proc. R. Soc. Tasm., 110, 157-216.

Scott, T.D., 1962: 'THE MARINE AND FRESHWATER FISHES OF SOUTH AUSTRALIA. Government Printer, Adelaide. 